\title{
DIFFERENT INFLUENCE OF COOPERATION AND PUBLIC FUNDING ON INNOVATION ACTIVITIES WITHIN GERMAN INDUSTRIES
}

\author{
Viktor PROKOP ${ }^{\star(D)}$, Jan STEJSKAL \\ Faculty of Economics and Administration, University of Pardubice, \\ Pardubice, Czech Republic
}

Received 14 September 2018; accepted 25 February 2018

\begin{abstract}
The aim of this research is to analyse (i) influence of cooperation with different partners and public funding on firms' willingness to innovate; (ii) how public funding and cooperation with different partners influence firms' innovation performance (turnover); (iii) effects of mutual interactions between firms' innovation activities, cooperation with different partners and public funding on firms' innovation performance (measured with turnover). The situation of 561 firms in Machines and Equipment industries in Germany was analysed because it is one of the most competitive economy in the world and one of the leaders in innovation within European Union. It allows to create unique benchmark and to propose implications that will be more appropriate and applicable also in other countries. For analyses, the data from Community Innovation Survey 2012-2014, which is a harmonized questionnaire and provides EU's science and technology statistics, was used, and new binary and multiple linear regression models were employed. Results of analyses show that provision of public subsidies, unlike cooperation, strongly influence firm's motivation to innovate. However, results also showed that supported innovation activities do not always lead to an increase in firms' innovative performance. Therefore, it can be pointed to the phenomenon of inefficiency of public innovation support in final consequence.
\end{abstract}

Keywords: cooperation, public funding, innovation activities, Germany, benchmark, CIS.

JEL Classification: F43, H21, H39.

\section{Introduction}

Many studies have demonstrated that innovations are realized more effectively, when they have suitable births conditions and environment. The innovation environment (milieu) or positive business environment is the set of these conditions, various subjects and linkages. The knowledge subjects are spread among them, such as scientific research institutes and universities (also entrepreneurial universities; Guerrero, Cunningham, \& Urbano, 2015).

*Corresponding author. E-mail: viktor.prokop@upce.cz 
Primarily economic and social interactions and number of various determinants influence each innovation environment. Interactions of the subjects on the market are in accordance with their business strategy (Autio \& Fu, 2015). However, firms have to produce their products in limited capabilities, in accordance with customer wishes (it includes also the price, quality, timing etc.), to win the competition at the global market. Due to changing conditions in global markets, many firms use the new sources to gain competitive advantage - particularly knowledge, creativity, innovativeness and cooperation. These elements are becoming increasingly the integral part of every innovation environment. However, not every entity is able to exploit the full potential of its environment to create innovations and to benefit from positive knowledge spillovers.

For these reasons, there is a growing role of state and its interventions as the specific part of each business (innovation) environment. The state and its entities have an interest in success of the firms (firms help to increase GDP, value added, employment, increase the average wage of their employees etc.). The growing wealth of the workers leads to higher consumption and, by extension, greater prosperity and welfare of society in individual regions. For these reasons, the state or municipality seeks to promote innovative activity of the firms and the creation of knowledge spillover effects. The firms' ability to cooperate and create the innovations is supported by various public aid and subsidies (Spieth, Schneckenberg, \& Ricart, 2014). Many developed countries governments invest to the knowledge acquisitions, transfers and knowledge spillovers to develop the purposeful activity that is aimed at creating an innovative product or service (hereinafter referred to as "innovation activity" or "innovation").

Following the above mentioned reasons, the focus of this research is to analyse the influence of public funding and cooperation with different partners on firms' innovation activities and growth of firms' turnover. Specifically, it was necessary to propose own research model to analyse (i) influence of cooperation with different partners and public funding on firms' willingness to innovate; (ii) how public funding and cooperation with different partners influence firms' innovation performance (turnover); (iii) effects of mutual interactions between firms' innovation activities, cooperation with different partners and public funding on firms' innovation performance (measured with turnover).

The remainder of this paper is structured as follows. In the next section, the theoretical background for the innovation backgrounds and environment is presented. Section 2 provides the characteristics of the dataset and the research methodology. Section 3 provides the experimental results and discussion of the obtained results and conclusions of the paper can be found.

\section{Theoretical background}

The business environment, in which is possible to find the above subjects and processes, the principles of cooperation and expected outputs, is called an innovation system (Borrás \& Edquist, 2013). The innovation system can be analysed on a transnational - global level. It covers commercial transactions and knowledge transfers across nations. These transfers of knowledge are evident in the character of product development (visible in patent assignees), manufacturing, and installation, which commonly involve a number of different firms and 
nations. Because of the international nature of this process, analysis of narrower (e.g. firm or nation specific) datasets may fail to capture the innovation and commercial cycle (Bettencourt, Trancik, \& Kaur, 2013). Other scholars argue that, the global innovation systems is the only framework for innovation activities and support (Cook, 2013). In practice, it is difficult to analyse global systems.

Therefore, in the 80 s of the 20 th century, attention was drawn to the national innovation systems (NIS). The systems, realized at the national level, help to create a positive business environment only in a general framework. The concept of the national innovation system has been gaining popularity as a core conceptual framework for analysing technological change, which is considered to be an indispensable foundation of the long-term economic development of a nation (Lundvall, 1992). Many scholars highlight that, the national innovation system is a useful framework for public policy application. But the effectiveness of this tool varies between the developing and developed countries (Intarakumnerd, Chairatana, \& Tangchitpiboon, 2002). Some scholars conclude that governments can formulate and implement economic policies on national level that do not simply reflect individual firms. However, they have sufficient and positive linkages with other actors, especially the private non-governmental organizations sectors. The practice shows that NIS should constitute the public policy framework; however, it cannot be a tool for the development of all regions in the country (Claisse \& Delvenne, 2016). Every region develops at different pace; some measures in some regions may not be applicable at all etc. (Ács, Autio, \& Szerb, 2014). This was the basis for change and shift of the attention to the innovation systems at the regional level.

The regional innovation systems are more important since the 90 s of the 20th century (Doloreux \& Porto Gomez, 2017). This type of system usually combines three sets of entities: private (firms); public (government); knowledge (universities), and helps them to cooperate and create innovative outputs. Carreira and Lopes (2018) stated that regional (and local) innovation systems (RIS), the process of interactive learning and systemic innovation has a strong local dimension, as spatial, institutional and cultural proximity favours closer links, as well as stable knowledge partnering among different types of actors. The dense network of vertical and horizontal relations between actors is crucial for this type of networking. They further report that the territorial system in which firms operate is shaped by a set of "soft" factors (for example, norms, codes of conducts, modes of social regulation) and is characterized by specific infrastructure (transport, telecom), knowledge providers (universities, research institutes, technology transfer centres, etc.), and governance mechanisms, which often work through institutions such as government departments, as well as private business associations, chambers of commerce and development, training and promotion agencies (Merickova, Nemec, \& Svidronova, 2015).

The regional actors have among themselves the various knowledge-based or cooperative-based relationships and ties. These relationships have been described by Leydesdorff and Etzkowitz (1998) and are well-known as Triple-helix principle. In this context it should be noted that some studies highlight the unclear role of public bodies, especially national or regional governments (Etzkowitz, 2003). Many studies perceive their effects 
rather negatively. The positive impact of public interventions in regional innovation systems has been reported e.g. by Coenen, Asheim, Bugge, and Herstad (2017). They point to the character of fiscal aid, but some of them point to the need to have a diversity in support (not to provide the support of type "can watering"), further to the need for a clear aim (determining measurable objectives with clear time horizons) and to an agreement on the use of appropriate tools to achieve these goals.

If the subjects cooperate (in the regional innovation system or other networking) on various projects and knowledge-based activities, the knowledge spill-over effects are a natural consequence of these activities (Huggins, Izushi, Prokop, \& Thompson, 2014). It is the unintended effect that occur just when cooperating. It is a specific form of knowledge diffusion and enriching by its application in practice (Prochazka \& Hajek, 2015). So that they may occur, at least two main subjects (transmitter and receiver) of the learning process must be present. And these subjects must be in collaboration. It should be noted that it is a long process; the results cannot be predicted in advance in any way (Carreira \& Lopes, 2018). In the positive case the knowledge spill-over effects become a major determinant of innovation processes in firms (Prokop \& Stejskal, 2017). All R\&D expenditures that are invested from the firm, university or the state (municipal) budget in this learning process are a very risky investment. In addition, many studies have shown the positive effect of knowledge spill-over effects, but also highlight the difficulties in measuring the knowledge spillover processes (Braunerhjelm, Ding, \& Thulin, 2018). Indeed they concluded that there are different influences of knowledge spillovers on innovation activities within various industries and countries (Corrocher \& Cusmano, 2014).

For the reasons mentioned above, it was necessary to study the most important variables influencing the innovation capabilities in German Machines and Equipment industries. Generally, Germany represent the group of countries that are able to develop their innovation potential and one of the global leaders in innovation and competitiveness, not only in the context of the knowledge economy. One of the reasons is that the German government supports innovation and private investment in R\&D (Germany: STI Outlook, 2014). However, there is a lack of studies analysing determinants of innovation performance in Germany. Niebuhr and Peters (2012) analysed relation between labour diversity and firms' innovation activities in Germany; Robin and Schubert (2013) analysed the influence of firms' cooperation with public research centers on firms' innovation activities (product and process) in Germany and France; Czarnitzki and Lopes-Bento (2014) analysed the influence of national and European public funding on innovation inputs and outputs at firm level in Germany. However, there are no studies analysing these effects together and analysing whether these determinants influence innovation performance in a positive or negative way.

Moreover, national and European public policies are aimed at supporting cooperation between the private and public sector. However, these collaborations (supported from national funds) are not always efficient (Merickova, Prokop, \& Stejskal, 2016). Therefore, it is necessary to follow these arguments and create own research model (see Figure 1) to reach the aim of this study mentioned above. 


\section{Research methodology}

Data for analyses were obtained from Community Innovation Survey 2012-2014. Community Innovation Survey (CIS) is a harmonized questionnaire, part of the EU's science and technology statistics and is carried out every two years by the EU member states and a number of ESS member countries. This is the latest data currently available at the Eurostat (the delay in publishing micro data allowing broad international macroeconomic analyses is about 4 years). The survey is limited to firms with at least 10 employees. Note that, not all firms in the sample answered all questions. Therefore, missing data had to be treated. The common procedure for this task was used. It was necessary to replace the missing values with median values of the respective country and industry.

The methodological process of the research is based on own proposed research model (see Figure 1) and consists of following steps:

First, this study analyses the influence of firms' cooperation with different partners and public funding on firms' willingness to innovate and define following research questions (RQ):

RQ1: What factors influence firms' willingness to innovate?

a) the cooperation with which partner does most influence firms' willingness to introduce product / service / process innovation?

b) how public funding does influence the firms' willingness to introduce product / service / process innovation?

Second, the study analyses how public funding and cooperation with different partners influence firms' innovation performance (turnover) and define following research questions:

RQ2: What factors influence firms' innovation performance (turnover)?

a) how cooperation with different partners does influence the firms' innovation performance (turnover)?

b) how public funding does influence the firms' innovation performance (turnover)?

Third, study investigates the effects of mutual interactions between firms' innovation activities, cooperation with different partners and public funding on firms' innovation performance (turnover) and define following research question:

RQ3: What are the impacts of mutual interactions between firms' innovation activities, cooperation with different partners and public funding on firms' innovation performance (measured with firms' turnover)?

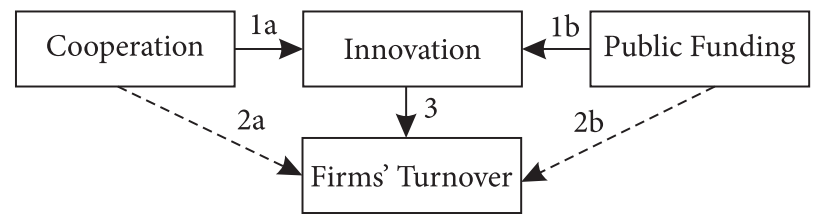

Figure 1. Proposal of own research model (source: own elaboration)

In the first step, the relationship between a set of explanatory variables (cooperation, public funding) and discrete responses (willingness to innovate) by using binary logistic regression models is explored. The discrete - binary response $\mathrm{Y}$ of an individual unit can take 
only two values, denoted by 0 or 1 (to innovate $=1$; not to innovate $=0$ ) similar to previous related studies (e.g. Coad \& Rao, 2008; Retherford \& Choe, 2011; Schneider \& Spieth, 2013 or Chatterjee \& Hadi, 2013).

In the second and third step, the relationship between one continuous dependent variable and a number of different categorical and continuous variables (see Table 1) by using multiple linear regression models was analysed. The dependent variable is the firms' turnover (innovation performance) represented by the $\%$ of turnover in new or improved products introduced during 2012-2014. The optimal time delay between input and output variables was analysed by number of researchers (e.g. Hollanders \& Celikel-Esser, 2007; Wang \& Huang, 2007). Grilliches (1990) empirically proved that there is no time delay with significant impact on the results of analyses. Therefore, analysed data were obtained without expecting time delay between inputs and outputs. This could be a limitation of this study. Two variables were also added to the model as control variables ( $R \& D$ expenditures and participation in the group of enterprises).

In total, this study analysed 561 firms in Machines and Equipment industries (NACE 28, 33). Verifying whether the data from CIS were correlated was conducted by using Spearman's test. All calculations were made in statistical software's IBM SPSS and STATISTICA (StatSoft Inc., 2011). Values of Spearman's test rejected the hypothesis that the data are correlated at the level of significance $\mathrm{p}<0.05$. After fulfilling the first prerequisite (uncorrelated data) and refusal to multicollinearity in the model, the analysis itself was conducted.

Selected are shown in Table 1. These independent variables were divided into following groups:

- Cooperation that represents one of the most important sources of competitive advantage. Cooperation with a diverse set of partners leads to learning opportunities with regard to both cooperation and innovation skills and hence is expected to enhance the firm's performance (Van Beers \& Zand, 2014). For example, cooperation with firms within enterprise groups provide knowledge and resources from their wider groups (Tether, 2002); cooperation with universities that are seen as generators of new knowledge and university research which is a key component of nation's innovative capacity (Gulbranson \& Audretsch, 2008).

- Innovation while different innovation activities significantly influence the firm performance (Camisón \& Villar-López, 2014). However, patterns in innovation structures are becoming increasingly diverse, complex and nonlinear (Hajek \& Henriques, 2017) and, therefore, there are growing significant differences in innovation activities and performance. Therefore, there is a need to distinguish between different types of innovation (e.g. goods, services and processes) and measure their influence on firms' performance independently.

- Financing which provide additional financial sources that could support firms' innovation. The use of public funding to foster private research and development (R\&D) activities is a common practice in many countries (Zúñiga-Vicente, Alonso-Borrego, Forcadell, \& Galán, 2014). On the other hand, these financial sources influence firms' performance differently. Prokop, Stejskal, and Hajek (2018) also show that these sources could be inefficient in specific cases. For these reasons, it was necessary to separate different kinds of financing.

- Control variables that include R\&D expenditures that can support firms' R\&D ac- 
tivities, which create an organizational climate that, is propitious to questioning, thus favoring the flexibility of firms, their capacity to integrate new concepts and their adaptability to market changes (Raymond \& St-Pierre, 2010). Participation in the groups of enterprises while firms that belong to the enterprise group are better informed of the capabilities of potential partners due to knowledge pooling and the activities of other members of their group - it can help them for example to reduce costs and bring benefits from knowledge spillovers (Tether, 2002).

Table 1. Independent variables used in models

\begin{tabular}{|c|c|c|c|}
\hline Cooperation & Innovation & Financing & Control Var. \\
\hline COUNI & INN_G & FUNLOC & RDEXP \\
\hline COGP & INN_S & FUNGMT & GP \\
\hline COSUP & INN_P & FUNEU & \\
\hline COGOV & & & \\
\hline
\end{tabular}

Legend: COUNI - co-operation partner: universities or other higher education institutions, COGP co-operation partner: other enterprises within enterprise group, COSUP - co-operation partner: Suppliers of equipment, materials, components, or software, clients or customers, COGOV - co-operation partner: government or public research institutes, INN_G - introduced onto the market a new or significantly improved good, INN_S - introduced onto the market a new or significantly improved service, INN_P - introduced onto the market a new or significantly improved process (method of production; logistic, delivery or distribution system; supporting activities), FUNLOC - Public funding from local or regional authorities; FUNGMT - public funding from central government, FUNEU public financial support from the EU, RDEXP - firms' expenditures on innovation activities; GP - part of the group of enterprises.

\section{Results and discussion}

In the following part, the results of regression models are shown. Firstly, the effects of cooperation with different partners and provision of public subsidies from local, national and European funds on firms' willingness to innovate are investigated. Results in Table 2 show that public subsidies are a strong incentive for German Machines and Equipment firms to produce various types of innovation (RQ1b). These results support results already published in various works, for example Bronzini and Piselli (2016) proved impact of R\&D subsidies on firm innovation (patent applications) in Italy; D. Guo, Y. Guo, and Jiang (2016) examined the effects of government-subsidized R\&D on firm innovation outputs (number of patents, sales from new products, and exports) in China.

On the contrary, the results show that it is not significantly important for the innovation creation whether or not firms cooperate in innovation processes (RQ1a). Just the collaboration in group of firms has a significant impact on the process innovation. Lhuillery and Pfister (2009) studied the same situation in France based on CIS data. They stated that firms' collaboration with universities or other partners suffer from the time delay of the outputs, high financial demands and inoperative cooperative structures. Lhuillery and Pfister have called it as "cooperation failures". Based on these results, it cannot unambiguously be confirmed that even German firms are failing because the causal links have not been investigated. However, the results of regression models confirm the insignificant impact of co-operation 
on innovation. Some results (though not significant) indicate a negative impact on innovation activities.

Table 2. Influence of public funding and cooperation on firms' willingness to innovate (source: own processing)

\begin{tabular}{|r|c|c|c|}
\hline & Goods Innov. & Services Innov. & Processes Innov. \\
\cline { 2 - 4 } & $p$-value $(\beta)$ & $p$-value $(\beta)$ & $p$-value $(\beta)$ \\
\hline Cooperation (RQ1a) & & & \\
\hline COGP & $.305(.711)$ & $.988(-.010)$ & $.010(1.454)^{* *}$ \\
\hline COSUP & $.277(-.542)$ & $.276(.693)$ & $.747(.144)$ \\
\hline COGOV & $.113(.788)$ & $.922(-.068)$ & $.062(.830)^{\star}$ \\
\hline Public funding (RQ1b) & $.794(.140)$ & $.904(.086)$ & $.286(.493)$ \\
\hline FUNLOC & $.002(1.737)^{* * *}$ & $.000(2.390)^{* * *}$ & $.001(1.482)^{* * *}$ \\
\hline FUNGMT & $.000(2.623)^{* * *}$ & $.061(1.091)^{\star}$ & $.000(1.467)^{* * *}$ \\
\hline FUNEU & $.000(2.469)^{* * *}$ & $.000(2.236)^{* * *}$ & $.004(1.241)^{* * *}$ \\
\hline$r^{2}-$ Nagelkerke & .581 & .465 & .491 \\
\hline$r^{2}-$ Cox \& Snell & .433 & .229 & .340 \\
\hline-2 Log likelihood & 211.491 & 110.000 & 201.504 \\
\hline Correctly predicted $(\%)$ & 84.8 & 91.3 & 78.8 \\
\hline
\end{tabular}

Legend: ${ }^{\star}$ statistically significant at $p=.10,{ }^{\star *}$ at $p=.05$ and ${ }^{\star * *}$ at $p=.01$.

In the second phase of the research, the multiple regression model to analyse influence of innovation activities, cooperation with different partners and public subsidies on firms' turnover (innovation performance) was used. The correlation coefficient $\mathrm{R}$ of the research model reached the value of .951 and the coefficient of determination R2 reached .905. P-value was measured at .000 . P-value showed that research model is significant at $\mathrm{p}<.01$ and therefore there was a rejection of the null hypothesis and the model could be regarded as significant.

Table 3 shows individual (direct) effects of selected determinants mentioned above. Results show that service innovation, European funds, cooperation with universities and government and expenditures to research and development (innovation expenditures) positively and significantly influence firms' innovation performance.

Examination of the direct influence of individual variables on the dependent variable showed rather surprising results. The results confirmed a negative impact of some variables: local and national funding. This confirms the assumption that the provision of public support from local and national budgets does not necessarily lead to the intended effects of enhancing innovation capabilities and the production of innovation (RQ2b). This can be explained by the small amount of provided public funds, or support of localization or incentives, investment, or environmental measures. The results lead surprisingly to negative results with product innovation or collaboration based on supplier-customer base or on group of firms' base (RQ2a). 
Table 3. Direct effects of selected determinants on firms' turnover from innovations (source: own processing)

\begin{tabular}{|c|c|}
\hline & Firms' Turnover \\
\cline { 2 - 2 } & $p$-value $(\beta)$ \\
\hline Innovation type & $.000(-9.524)^{\star * *}$ \\
\hline INN_G & $.040(1.343)^{\star *}$ \\
\hline INN_S & $.530(1.183)$ \\
\hline INN_P & \\
\hline Public funding & $.001(-7.320)^{* * *}$ \\
\hline FUNLOC & $.022(-5.936)^{\star *}$ \\
\hline FUNGMT & $.000(4.969)^{\star * *}$ \\
\hline FUNEU & $.000(-3.834)^{* * *}$ \\
\hline Cooperation & $.000(-3.527)^{\star * *}$ \\
\hline COGP & $.001(3.130)^{\star * *}$ \\
\hline COSUP & $.000(4.362)^{\star * *}$ \\
\hline COUNI & \\
\hline COGOV & $.041(0.106)^{\star *}$ \\
\hline Control Var. & $0.418(-0.342)$ \\
\hline RDEXPT & \\
\hline GP & \\
\hline
\end{tabular}

Legend: ${ }^{\star}$ statistically significant at $p=.10,{ }^{\star \star}$ at $p=.05$ and ${ }^{\star \star \star}$ at $p=.01$.

However, in practice combinations of variables occur more often. The firms are expecting synergic effects or knowledge spillover effects. Therefore, various combinations of innovations with the variables examined (types of cooperation and financial funds) were analysed. The results are summarized in Table 4.

Table 4. Effects of mutual interactions between selected determinants on firms' turnover from innovations (source: own processing)

\begin{tabular}{|c|c|c|c|}
\hline & Goods Innov. & Services Innov. & Processes Innov. \\
\hline & $p$-value $(\beta)$ & $p$-value $(\beta)$ & $p$-value $(\beta)$ \\
\hline \multicolumn{4}{|l|}{ Public funding } \\
\hline FUNLOC & $.001(-3.863)^{\star * *}$ & $.000(6.120)^{\star \star \star *}$ & $.001(-5.590)^{* * *}$ \\
\hline FUNGMT & $.007(-4.161)^{\star * *}$ & $.008(5.074)^{* * *}$ & $.000(1.839)^{\star * *}$ \\
\hline FUNEU & $.0150(2.274)^{\star *}$ & $.002(-2.365)^{\star * *}$ & $.868(0.052)$ \\
\hline \multicolumn{4}{|l|}{ Cooperation } \\
\hline COGP & $.631(-0.130)$ & $.000(2.681)^{\star \star \star}$ & $.003(-1.794)^{* * *}$ \\
\hline COSUP & $.000(0.623)^{\star * *}$ & $.009(1.818)^{\star * *}$ & $.000(-2,210)^{* * *}$ \\
\hline COUNI & $.000(-2.544)^{\star * *}$ & $.003(-2.406)^{\star * *}$ & $.000(2.263)^{\star \star \star}$ \\
\hline COGOV & $.010(0.372)^{\star \star}$ & $.000(-3.760)^{\star * *}$ & $.795(-0.063)$ \\
\hline
\end{tabular}

Legend: ${ }^{\star}$ statistically significant at $p=.10,{ }^{* *}$ at $p=.05$ and ${ }^{* * *}$ at $p=.01$. 
The results in Table 4 answer RQ3 and show that if public support from local and national budgets is targeted to the right type of innovation, a significant positive impact can be achieved. The result of these innovation processes is the output that succeeds in the markets; it is commercialized and increases the turnover of the firms (such as public support for the creation of service innovation in analysed industrial branch in Germany).

In cooperation, the situation is similar. The results show that cooperation with universities rather reduces the revenues from innovative activities aimed at creating the most important innovations (productions and services). The results can be labelled as unequal and unambiguous, recommendations cannot be derived from them. It turns out that other mutual combinations of variables, which are in practice, need to be examined.

\section{Conclusions}

Nowadays, innovations represent key factors in the process of gaining competitive advantage. Firms are therefore pushing to innovate. However, there are number of limitations that do not allow firms to be successful during innovation processes. For example, insufficient financial resources, knowledge base, and technology limit firms. For these reasons, firms are finding cooperation partners to gain external knowledge, share costs, technologies and to build up innovation partnerships. EU and national governments support these cooperation's, as well as firms' creation of innovation. However, there is a growing question as to whether these activities lead to the creation of innovation that really influence firms' performance (turnover) and helps them to gain competitive advantage.

Results of this study show that public funding significantly influence firms' willingness to innovate. It is in accordance with previous studies, e.g. Bronzini and Piselli (2016) proved the impact of R\&D subsidies on firm innovation in Italy. Broekel, Fornahl, and Morrison (2015) also showed that subsidies for R\&D cooperation are a suitable policy measure for stimulating the innovation efficiency of regions in Germany. In contrary, these subsequent results show that these innovation activities do not lead to the growth of firms' innovation performance. This situation can be called as "phenomenon of inefficiency in public innovation support." Dai and Cheng (2015) reached similar results and showed that public subsidies on corporate $\mathrm{R} \& \mathrm{D}$ investment varies with different levels of public subsidies and evaluated the effect of varying degrees of public subsidy on firms' R\&D effort. This phenomenon can be preceded by consistently defined rules of supporting financial programs, emphasizing the outcomes and their implications of innovation projects, not just projects' outputs. Moreover, inappropriate targeting of public funds (mostly local and national) could lead to significant decrease of firms' innovation performance. Similarly, cooperation with various partners leads to decrease of firms' innovation performance in a number of cases. Surprisingly, firms are not motivated to cooperate on innovation activities, except cooperation on process innovations within groups of enterprises and with universities.

Following the results above, it can be proposed creating better conditions for cooperation between firms, specifically within groups of companies and public research institutes (universities). For example, through suitable financial support for particular industrial branch, tax benefits, incentives, revised public policy of education, regional policy etc. There is also need 
to deepen the trust between companies because it could support the share of knowledge and expenditures. Moreover, firms that belong to company groups are able to draw on resources from within their groups and prestige of their groups in seeking partners for innovation. Nowadays, there is also problem that firms and public entities have different interests and expectations (e.g., firms want to increase their profits and to protect their knowledge; however, universities and its researchers must publish and share knowledge). Therefore, it must be also proposed to find common interests (targets) between firms and public institutions for example in the various kinds of conjoint projects.

It should be remembered some limitations of this research. The first limitation is the data that was used in the research. Dataset was published by Eurostat with a long delay. Therefore, research outputs correspond to the situation in 2014. However, it can be assumed that due to the overall time lag in economies, the results can be considered significant. Second limitation is the explanatory power of the data and the results, which applies only to the selected industry and the state. Third limitation is that analysed data were obtained without expecting time delay between inputs and outputs. For the future research, it must be realized the comparison between industries as well as between countries and deeply analyse the influence of other determinants of the knowledge economy on firms' innovation performance.

\section{Acknowledgements}

This work was supported by a grant provided by the scientific research project of the Czech Sciences Foundation Grant No: 17-11795S.

\section{Author contributions}

VP and JS collaborated to process the whole paper equally.

\section{Disclosure statement}

Authors have no conflicts of interest to disclose.

\section{References}

Ács, Z. J., Autio, E., \& Szerb, L. (2014). National systems of entrepreneurship: Measurement issues and policy implications. Research Policy, 43(3), 476-494. https://doi.org/10.1016/j.respol.2013.08.016

Autio, E., \& Fu, K. (2015). Economic and political institutions and entry into formal and informal entrepreneurship. Asia Pacific Journal of Management, 32(1), 67-94. https://doi.org/10.1007/s10490-014-9381-0

Bettencourt, L. M., Trancik, J. E., \& Kaur, J. (2013). Determinants of the pace of global innovation in energy technologies. PLoS One, 8(10). https://doi.org/10.1371/journal.pone.0067864

Borradaile, G. J. (2013). Statistics of earth science data: their distribution in time, space and orientation. Springer Science \& Business Media.

Borrás, S., \& Edquist, C. (2013). The choice of innovation policy instruments. Technological Forecasting and Social Change, 80(8), 1513-1522. https://doi.org/10.1016/j.techfore.2013.03.002 
Braunerhjelm, P., Ding, D., \& Thulin, P. (2018). The knowledge spillover theory of intrapreneurship. Small business economics, 51(1), 1-30. https://doi.org/10.1007/s11187-017-9928-9

Broekel, T., Fornahl, D., \& Morrison, A. (2015). Another cluster premium: Innovation subsidies and R\&D collaboration networks. Research policy, 44(8), 1431-1444. https://doi.org/10.1016/j.respol.2015.05.002

Bronzini, R., \& Piselli, P. (2016). The impact of R\&D subsidies on firm innovation. Research Policy, 45(2), 442-457. https://doi.org/10.1016/j.respol.2015.10.008

Camisón, C., \& Villar-López, A. (2014). Organizational innovation as an enabler of technological innovation capabilities and firm performance. Journal of Business Research, 67(1), 2891-2902. https://doi.org/10.1016/j.jbusres.2012.06.004

Carreira, C., \& Lopes, L. (2018). Regional knowledge spillovers: a firm-based analysis of non-linear effects. Regional Studies, 52(7), 948-958. https://doi.org/10.1080/00343404.2017.1360484

Chatterjee, S., \& Hadi, A. S. (2013). Regression analysis by example. John Wiley \& Sons.

Claisse, F., \& Delvenne, P. (2016). As above, so below? Narrative salience and side effects of national innovation systems. Critical Policy Studies, 11(3), 1-17. https://doi.org/10.1080/19460171.2015.1119051

Coad, A., \& Rao, R. (2008). Innovation and firm growth in high-tech sectors: A quantile regression approach. Research policy, 37(4), 633-648. https://doi.org/10.1016/j.respol.2008.01.003

Coenen, L., Asheim, B., Bugge, M. M., \& Herstad, S. J. (2017). Advancing regional innovation systems: What does evolutionary economic geography bring to the policy table?. Environment and Planning C: Politics and Space, 35(4), 600-620. https://doi.org/10.1177/0263774X16646583

Cooke, P. (2013). Qualitative analysis and comparison of firm and system incumbents in the new ICT global innovation network. European Planning Studies, 21(9), 1323-1340.

https://doi.org/10.1080/09654313.2012.755828

Corrocher, N., \& Cusmano, L. (2014). The "KIBS engine" of regional innovation systems: Empirical evidence from European regions. Regional Studies, 48(7), 1212-1226. https://doi.org/10.1080/00343404.2012.731045

Czarnitzki, D., \& Lopes-Bento, C. (2014). Innovation subsidies: Does the funding source matter for innovation intensity and performance? Empirical evidence from Germany. Industry and Innovation, 21(5), 380-409. https://doi.org/10.1080/13662716.2014.973246

Dai, X., \& Cheng, L. (2015). The effect of public subsidies on corporate R\&D investment: An application of the generalized propensity score. Technological Forecasting and Social Change, 90, 410-419. https://doi.org/10.1016/j.techfore.2014.04.014

Doloreux, D., \& Porto Gomez, I. (2017). A review of (almost) 20 years of regional innovation systems research. European Planning Studies, 25(3), 371-387.

https://doi.org/10.1080/09654313.2016.1244516

Etzkowitz, H. (2003). Innovation in innovation: The triple helix of university-industry-government relations. Social Science Information, 42(3), 293-337. https://doi.org/10.1177/05390184030423002

Germany: STI Outlook. (2014). The innovation policy platform. Retrieved from https://www.innovationpolicyplatform.org/content/germany

Grilliches, Z. (1990). Patent statistics as economic indicators: a survey. Journal of Economic Literature, 28(4), 1661-1707.

Guerrero, M., Cunningham, J. A., \& Urbano, D. (2015). Economic impact of entrepreneurial universities' activities: An exploratory study of the United Kingdom. Research Policy, 44(3), 748-764. https:// doi.org/10.1016/j.respol.2014.10.008

Gulbranson, C. A., \& Audretsch, D. B. (2008). Proof of concept centers: accelerating the commercialization of university innovation. The Journal of Technology Transfer, 33(3), 249-258.

https://doi.org/10.1007/s10961-008-9086-y 
Guo, D., Guo, Y., \& Jiang, K. (2016). Government-subsidized R\&D and firm innovation: Evidence from China. Research policy, 45(6), 1129-1144. https://doi.org/10.1016/j.respol.2016.03.002

Hajek, P., \& Henriques, R. (2017). Modelling innovation performance of European regions using multioutput neural networks. PloS One, 12(10). https://doi.org/10.1371/journal.pone.0185755

Hollanders, H., \& Celikel-Esser, F. (2007). Measuring innovation efficiency. INNO Metrics.

Huggins, R., Izushi, H., Prokop, D., \& Thompson, P. (2014). Regional evolution and waves of growth: A knowledge-based perspective. Expert Systems with Applications, 41(12), 5573-5586. https://doi.org/10.1016/j.eswa.2014.02.008

Intarakumnerd, P., Chairatana, P. A., \& Tangchitpiboon, T. (2002). National innovation system in less successful developing countries: the case of Thailand. Research Policy, 31(8), 1445-1457. https://doi.org/10.1016/S0048-7333(02)00074-4

Leydesdorff, L., \& Etzkowitz, H. (1998). Triple Helix of innovation. Science and Public Policy, 25(6), 358-364.

Lhuillery, S., \& Pfister, E. (2009). R\&D cooperation and failures in innovation projects: Empirical evidence from French CIS data. Research Policy, 38(1), 45-57. https://doi.org/10.1016/j.respol.2008.09.002

Lundvall, B. Å. (1992). National systems of innovation: Towards a theory of innovation and interactive learning. London: Pinter Publishers.

Merickova, B. M., Nemec, J., \& Svidronova, M. (2015). Co-creation in local public services delivery innovation: Slovak experience. Lex Localis, 13(3), 521. https://doi.org/10.4335/13.3.521-535(2015)

Merickova, B., Prokop, V., \& Stejskal, J. (2016). Consequences of enterprises' cooperation within the innovation process - case study of the Czech Machinery Industry. E+M Ekonomie a Management, 19(3), 110-122. https://doi.org/10.15240/tul/001/2016-3-008

Niebuhr, A., \& Peters, C. (2012). Labour diversity and firm's innovation: Evidence from Germany. Nuremburg: IAB Institute for Employment Research.

Prochazka, O., \& Hajek, P. (2015). Modelling knowledge management processes using fuzzy cognitive maps. In International Conference on Knowledge Management in Organizations (pp. 41-50). Springer International Publishing. https://doi.org/10.1007/978-3-319-21009-4_4

Prokop, V., \& Stejskal, J. (2017). Different approaches to managing innovation activities: An analysis of strong, moderate, and modest innovators. Engineering Economics, 28(1), 47-55. https://doi.org/10.5755/j01.ee.28.1.16111

Prokop, V., Stejskal, J., \& Hajek, P. (2018). The influence of financial sourcing and collaboration on innovative company performance: A comparison of Czech, Slovak, Estonian, Lithuanian, Romanian, Croatian, Slovenian, and Hungarian case studies. In Knowledge Spillovers in Regional Innovation Systems (pp. 219-252). Springer, Cham. https://doi.org/10.1007/978-3-319-67029-4_8

Raymond, L., \& St-Pierre, J. (2010). R\&D as a determinant of innovation in manufacturing SMEs: An attempt at empirical clarification. Technovation, 30(1), 48-56.

https://doi.org/10.1016/j.technovation.2009.05.005

Retherford, R. D., \& Choe, M. K. (2011). Statistical models for causal analysis. New York: John Wiley.

Robin, S., \& Schubert, T. (2013). Cooperation with public research institutions and success in innovation: Evidence from France and Germany. Research Policy, 42(1), 149-166. https://doi.org/10.1016/j.respol.2012.06.002

Schneider, S., \& Spieth, P. (2013). Business model innovation: Towards an integrated future research agenda. International Journal of Innovation Management, 17(01), 1340001. https://doi.org/10.1142/S136391961340001X

Spieth, P., Schneckenberg, D., \& Ricart, J. E. (2014). Business model innovation-state of the art and future challenges for the field. $R \& D$ Management, 44(3), 237-247. https://doi.org/10.1111/radm.12071 
StatSoft, Inc. (2011). STATISTICA (data analysis software system), version 10. Retrieved from www. statsoft.com

Tether, B. S. (2002). Who co-operates for innovation, and why: an empirical analysis. Research Policy, 31(6), 947-967. https://doi.org/10.1016/S0048-7333(01)00172-X

Van Beers, C., \& Zand, F. (2014). R\&D cooperation, partner diversity, and innovation performance: an empirical analysis. Journal of Product Innovation Management, 31(2), 292-312. https://doi.org/10.1111/jpim.12096

Wang, E. C., \& Huang, W. (2007). Relative efficiency of R\&D activities: A cross-country study accounting for environmental factors in the DEA approach. Research Policy, 36(2), 260-273. https://doi.org/10.1016/j.respol.2006.11.004

Zúñiga-Vicente, J. Á., Alonso-Borrego, C., Forcadell, F. J., \& Galán, J. I. (2014). Assessing the effect of public subsidies on firm R\&D investment: a survey. Journal of Economic Surveys, 28(1), 36-67. https://doi.org/10.1111/j.1467-6419.2012.00738.x 